\title{
The monasteries of the diocese of Würzburg as a WebGIS-project
}

\section{Michael Weisenberger}

GIS-technology combined with spatial and temporal databases will be getting more influential in humanistic studies within the next few years. At the moment a lot of maps are being created with GIS-programs. The integrated and external databases allow dealing with huge datasets for the purpose of analysis. As prices for commercial licenses are very high, open source projects offer a great opportunity to use this kind of technology without paying a lot of money. The GIS for the history of the monasteries in the diocese of Würzburg presented in this paper was created only by the use of the open source applications QuantumGIS with PostgreSQL and PostGIS for the desktop GIS, MySQL and OpenLayers for the web-application. This study will show one exemplary way of publishing a historical WebGIS using the example of the monasteries in the diocese of Würzburg. A lot of maps showing the monastery landscape of the diocese of Würzburg at different times were published in the past ${ }^{1}$, but by using GIS-technology connected with spatio-temporal databases it is possible to show the whole development. The database consists

\footnotetext{
1 For example see: S. Petersen, Die geistlichen Gemeinschaften im mittelalterlichen Bistum Würzburg. Ein Überblick, in: Franken und Südtirol, ed. H. Flachenecker, H. Heiss, Innsbruck 2013, pp. 157-267; E. Gatz, Atlas zur Kirche in Geschichte und Gegenwart, Regensburg 2009, pp. 151, 219.

${ }^{2} \mathrm{~N}$. Backmund, Die Chorherrenorden und ihre Stifte in Bayern, Passau 1966; N. Backmund, Die Kollegiat- und Kanonissenstifte in Bayern, Winderg 1973.

${ }^{3}$ A. Wendehorst, S. Benz, Verzeichnis der Säkularkanonikerstifte der Reichskirche, „Jahrbuch für Fränkische Landesforschung”, 54, 1994, pp. 1-174.

${ }^{4}$ S. Petersen, Die süddeutschen Prämonstratenserstifte. Anfänge regionale Vernetzung - Kurienkontakt, Würzburg 2008.

5 W. Brückner, J. Lenssen, Zisterzienser in Franken, Würzburg 1991.

6J. Hemmerle, Die Benediktinerklöster in Bayern, Augsburg 1970.

7F. Jürgensmeier, Die benediktinischen Mönchs- und Nonnenklöster in Hessen, St. Ottilien 2004.

8F. Büll, Die Klöster Frankens bis zum neunten Jahrhundert, ,„Studien und Mitteilungen zur Geschichte des Benediktinerordens und seiner Zweige", 104, 1993, pp. 9-40.
}

of information extracted from the literature about the monasteries connected to the diocese of Würzburg. For the most orders there are overview studies, describing the development of their monasteries: the studies from Backmund ${ }^{2}$, Wendehorst and Benz ${ }^{3}$ about the Canons and the study from Petersen about the Premonstratensians in southern Germany ${ }^{4}$. Brückner and Lenssen ${ }^{5}$ were engaged in the history of the Cistercians. The volumes of the Germania Benedictina for Bavaria ${ }^{6}$ and Hes$\mathrm{sia}^{7}$ gave an overview about the history of the monasteries of the Benedictines and for Hessia also about the Cistercians. For the development of the Benedictines in Franconia the studies of Büll ${ }^{8}$, Störmer ${ }^{9}$, Wendehorst ${ }^{10}$ and the anthology of Hochholzer ${ }^{11}$ should be mentioned. Especially Büttner ${ }^{12}$ and $\mathrm{Hogg}^{13}$ dedicated themselves to the development of the Charthusians in Franconia. The volumes of the Bavaria Franciscana antiqua ${ }^{14}$ are concerned with the history of the Franciscan houses in Bavaria. The development of the Teutonic Order in Franconia was discussed in a study by Weiss ${ }^{15}$. Backmund ${ }^{16}$ gave an overview about

9 W. Störmer, Entwicklungstendenzen in der ostfränkischen Klosterlandschaft der Karolingerzeit, in: Mittelalterliche Klöster und Stifte in Bayern und Franken, ed. W. Störmer, St. Ottilien 2008, pp. 159-184.

$10 \mathrm{~A}$. Wendehorst, Das benediktinische Mönchtum im mittelalterlichen Franken, in: Untersuchungen zu Kloster und Stift, Göttingen 1980, pp. 38-60.

$11 \mathrm{E}$. Hochholzer, Benediktinisches Mönchtum in Franken vom 12. bis zum 17. Jahrhundert, Münsterschwarzach 2000.

12 K.-P. Büttner, Die unterfränkischen Kartausen, w: Kartäusermystik und Mystiker-, ed. J. L. Hogg, Salzburg 1981, pp. 56-82; K.-P. Büttner, Die fränkischen Kartausen, in: Die Geschichte des Kartäuserordens, vol. 1, ed. J. L. Hogg, Salzburg 1991, pp. 33-57.

13 See the articles in M. Koller, Kartäuser in Franken, Würzburg 1996.

14 Bavaria Franciscana Antiqua, München 1955-1961.

15 D. J. Weiss, Die Geschichte der Deutschordensballei Franken im Mittelalter, Neustadt a. d. Aisch 1991.

16 N. Backmund, Die kleineren Orden in Bayern und ihre Klöster bis zur Säkularisation, Windberg 1974. 


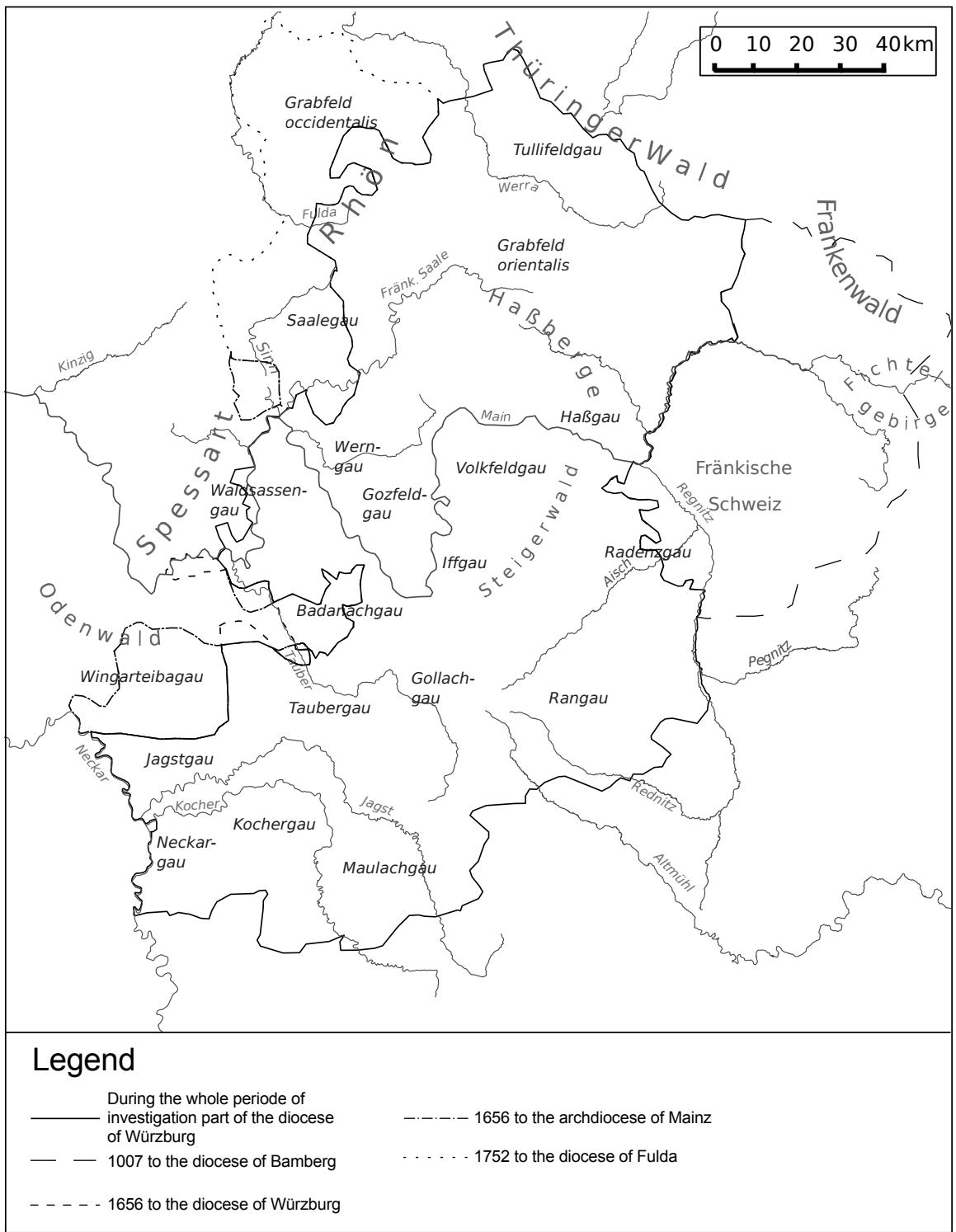

Map 1. Changes in the shape of the diocese of Würzburg (742-1818)

the smaller orders, Zumkeller about the Augustinians ${ }^{17}$, Decker about the Carmelites ${ }^{18}$ and Schmid about the Hermits of Saint Paul ${ }^{19}$.

${ }^{17}$ A. Zumkeller, Die Bedeutung der Augustiner für das kirchliche und religiöse Leben in Franken und Thüringen während des 14. Jahrhunderts, „Würzburger Diözesangeschichtsblätter”, 18-19, 1956-57, pp. 33-52.

18 A. Decker, Die Karmeliten in Bayern zwischen Reformation und Säkularisation, ,Zeitschrift für Bayerische Landesgeschichte“ " 53, 1990, pp. 3-49.
A good overview about the development of the monastery landscape of the diocese of Würzburg was published by Petersen in $2013^{20}$.

At first sight, the question about the spatial extent of this research seems to be a very

\footnotetext{
19 H. Schmid, Kurzlebige Pauliner-Klöster in Schwaben, Franken und am Oberrhein, ,Zeitschrift für Württembergische Landesgeschichte“, 45, 1986, pp. 103-116.

${ }^{20}$ S. Petersen, Die geistlichen Gemeinschaften, p. 168.
} 
easy one, but over the centuries the shape of the diocese has changed several times. At its foundation it included the eastern parts of the Waldsassen- and Saalegau, the Tullifeldgau, the Grabfeldgau, which was confined by the Rennsteig in the north, the Wern- Gozfeld-, Volkfeld-, and Haßgau, the Radenzgau up to the Fichtelgebierge, the eastern parts of the Wingarteiba-, Tauber- und Badanachgau, the Iffgau and the Neckar-, Jagst-, Kocher-, Maulach- and Rangau ${ }^{21}$. With the foundation of the diocese of Bamberg in the year 1007, the diocese of Würzburg lost about 5000 square kilometers of its eastern territory because of the separation of the Rangau and parts of the Volkfeldgau which are placed between the rivers Aurach and Regnitz ${ }^{22}$. Looking at the monasteries' history this change of the diocese's area is not important since no monastery was concerned. The liber synodalis from the middle of the $15^{\text {th }}$ century offers the oldest complete description of the area of the diocese of Würzburg. It names all archdeaconries and the associated "Landkapitel" including their parishes ${ }^{23}$. The history of several monasteries shows that the area changed several times within the period between 1007 and the middle of the $15^{\text {th }}$ century. The monastery Johannesberg near Hersfeld ${ }^{24}$ was part of the diocese only after 1042, Hünfeld ${ }^{25}$ and Rasdorf ${ }^{26}$ only after 1049 . In the middle of the $17^{\text {th }}$ century the extent of the diocese changed again as a result of assimilation of the counties Königstein and Rieneck into the bishopric of the archdiocese of Mainz. Concerning these areas Swathes were subordinated to the ecclesias-

\footnotetext{
21 A. Wendehorst, Das Bistum Würzburg, vol. 1, Berlin 1962, p. 17.

22 F. J. Bendel, Die Würzburger Bistumsmatrikel aus der Mitte des 15. Jahrhunderts, ,Würzburger Diözesangeschichtsblätter”, 2, 1934, pp. $1-46, p$. XXII. The latin text of the protocol of the Frankfurter Synode is printed with a German translation in F. Machilek, Das Protokoll der Frankfurter Synode vom 1. November 1007 und die Errichtung des Bistums Bamberg, in: Das Bistum Bamberg um 1007, ed. J. Urban, Bamberg 2006, pp. 16-44.

23 F. J. Bendel, Würzburger Bistumsmatrikel, p. III.

$24 \mathrm{~L}$. Unger, Johannesberg, in: Die benediktinischen Mönchs- und Nonnenklöster in Hessen, ed. F. Jürgensmeier, St. Ottilien 2004, pp. 630-632.

25 J. Burkardt, Hünfeld, in: Die benediktinischen Mönchs-, pp. 653-657.

26 J. Leinweber, J. Burkardt, Rasdorf, in: Die benediktinischen Mönchs-, pp. 910-912.
}

tic jurisdiction of the bishop of Würzburg. This caused problems which the Imperial Knights used to establish the reformation from the Peace of Augsburg on, which took place in the year 1555. Therefore the dioceses of Mainz and Würzburg were forced to unify their areas of responsibility. With the substitution of parishes from the year 1656 they aligned the areas of their ecclesiastical and profane dominions. But it took three years to play out the conditions of this contract. After the year 1659 the monastery of Gerlachsheim was made part of the diocese of Würzburg and the monasteries Amorbach and Seligenthal were made part of the diocese of Mainz ${ }^{27}$. For almost the next hundred years the shape of the diocese remained unchanged. It was only after the foundation of the diocese of Fulda in the area of the profane dominion of the imperial abbey in the year 1752 that the borders changed again. The diocese of Würzburg lost territories in the north-east. But the most important change of the shape of the diocese took place in the year 1818 during the circumscription of the Bavarian dioceses. The bulla Dei ac Domini Nostri on the $1^{\text {st }}$ of April 1818 aligned the borders of the dioceses with the country's frontiers. With the "Tegernseer Erklärung" of the $15^{\text {th }}$ of September 1821 the content of the bulla was put into practice $e^{28}$. The changes in the area of the diocese were so far-reaching that it is justifiable to end the study in that year.

After this short overview about the development of the area of the diocese of Würzburg, we will observe the development of the monaster-

\footnotetext{
27 The contract was edited by L. Steinel, Pfarreien-Austausch zwischen Würzburg und Mainz im Jahre 1656, „Freiburger-Diözesanarchiv", 37, 1909, pp. 224-231; F. Jürgensmeier, Diözesane Grenzkorrekturen und Beilegung territorialer Differenzen zwischen Kurmainz und Würzburg 1656, in: Beiträge zu Kirche, Staat und Geistesleben, ed. G. Christ, J. Schröder, R. Salzmann, Stuttgart 1994, pp. 113, 119-124; H. Flachenecker, Bistum Würzburg, in: Die Bistümer des Heiligen Römischen Reiches, ed. E. Gatz, C. Brodkorb, H. Flachenecker, Freiburg im Breisgau 2003, pp. 831-870.

28 D. Burkard, Rechtsfiktion und Rechtspraxis bei der Neuordnung der deutschen Bistumsgrenzen im 19. Jahrhundert, in: Bistümer und Bistumsgrenzen vom frühen Mittelalter bis zur Gegenwart, ed. E. Klueting, H. Klueting, H.-J. Schmidt, Rom 2006, pp. 219, 221-246.
} 


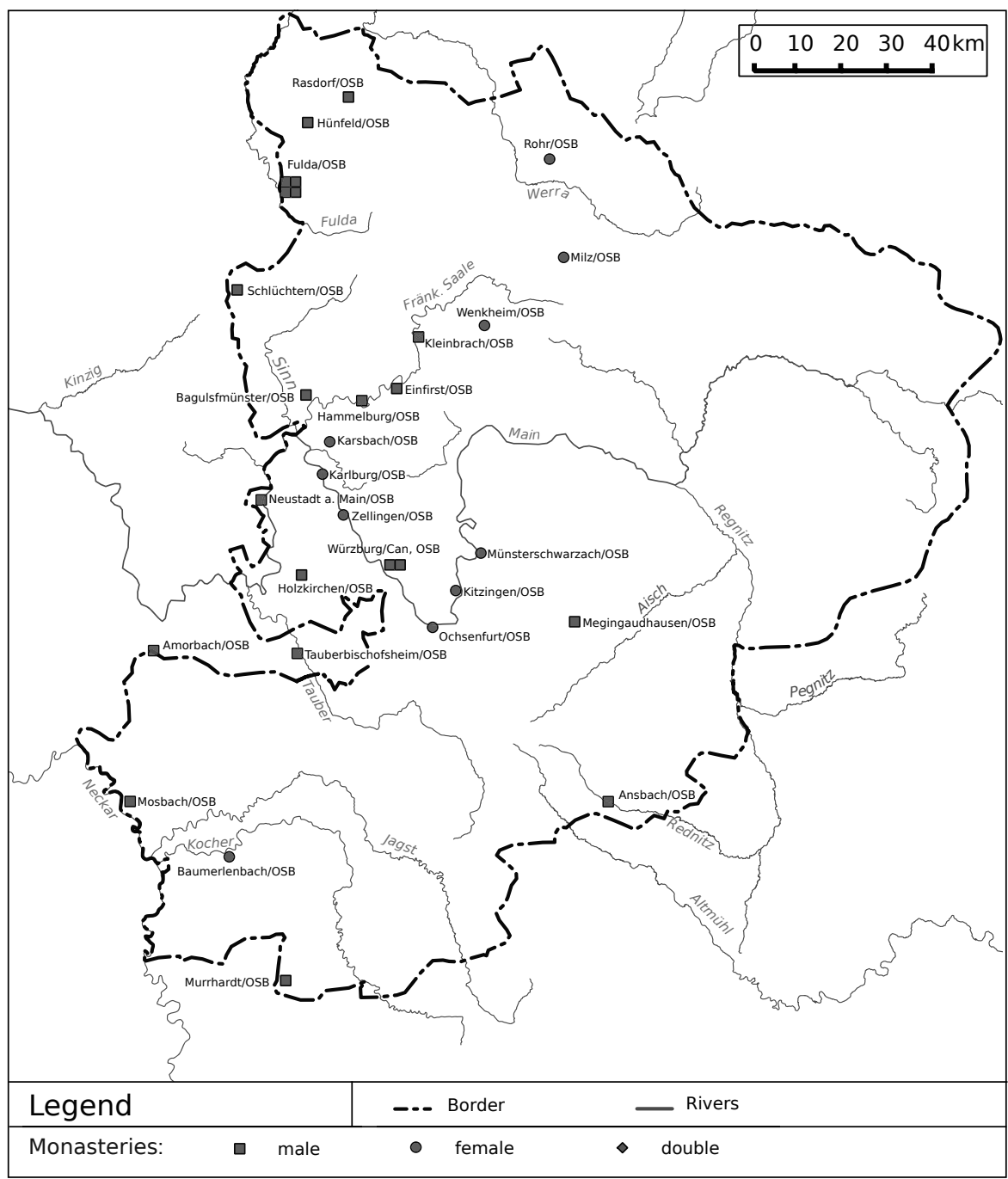

Map 2. The first period (till 900)

ies' dependence on this diocese ${ }^{29}$. The intersection of the diocese with monasteries took place in three different stages, separated by phases of stagnation or recession. The first stage started before the foundation of the diocese in the

29 See S. Petersen, Geistlichen Gemeinschaften, p. 168.

30 F. Büll, Klöster Frankens, p. 80.

31 W. Störmer, Zur kulturellen und politischen Bedeutung der Abtei Amorbach vom 8. bis zum frühen 12. Jahrhundert, in: Mittelalterliche Klöster und Stifte in Bayern und Franken, ed. W. Störmer, St. Ottilien 2008, pp. 202-206.

32 R. Koch, Das Kloster St. Gumbertus und Chorherrenstift St. Gumbert zu Ansbach, in: 1250 Jahre Bistum Würzburg, ed. J. Lenssen, L. Wamser, Würzburg 1992, pp. 229-234. year 742. At that time the monasteries of the Benedictines in Karlburg (before 659) ) $^{30}$ and Amorbach (around 734) ${ }^{31}$ already existed. The monasteries in Ansbach (before 748) ${ }^{32}$, Einfirst (before 788) ${ }^{33}$, Ochsenfurt (around 732) ${ }^{34}$ and

\footnotetext{
33 In the year 788 the monastery in Einfirst was donated to the monastery in Fulda by the brothers Megingoz and Matto. Lübeck assumed that the monastery was founded before the foundation of the monastery in Fulda and that the foundation took place in the years between 730 and 740. Probably the monastery in Einfirst is identical with the monastery documented in 814 in Mattenzell. See K. Lübeck, Fuldaer Nebenklöster in Mainfranken, „Mainfränkisches Jahrbuch für Geschichte und Kunst", 2, 1950, pp. 1-52; F. Büll, Klöster Frankens, pp. 27-29.

34 F. Büll, Klöster Frankens, p. 17.
} 


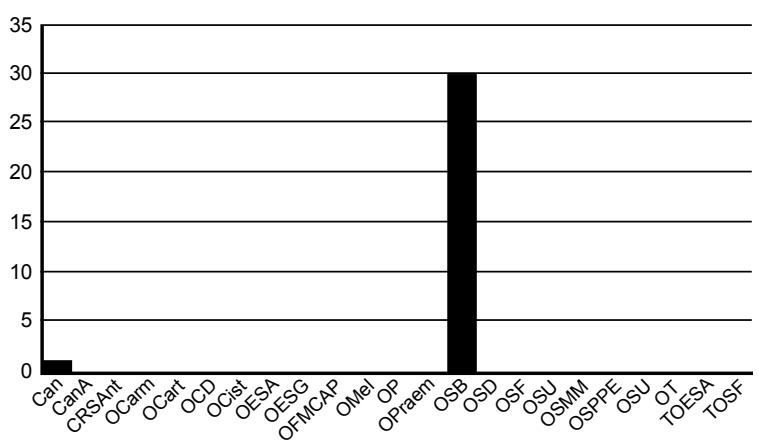

Fig. 1. Number of foundations during the first period

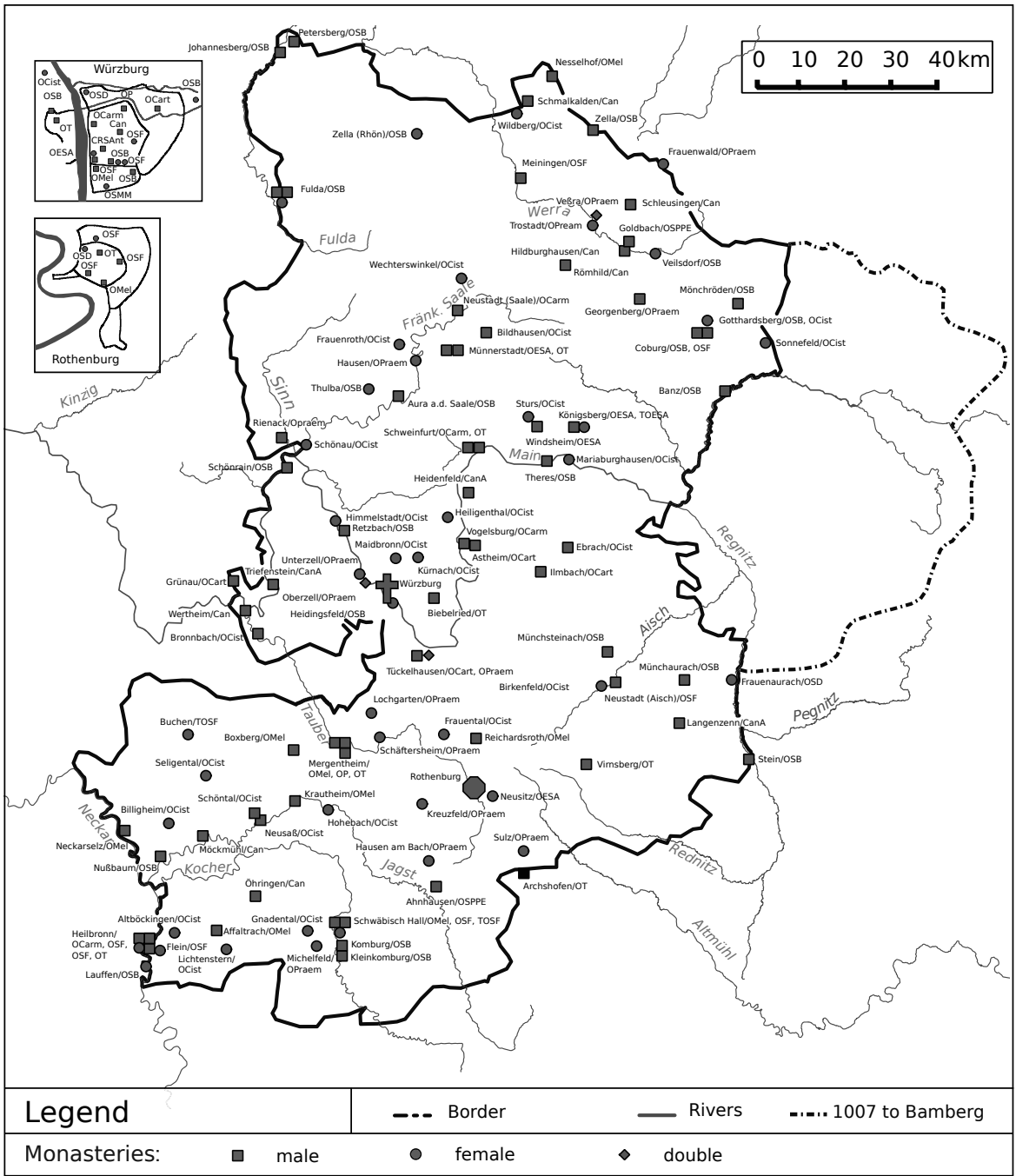

Map 3. The second period (1000-1524) 
Mosbach (around 740) ${ }^{35}$ were probably also founded earlier. The first period ended in the late $9^{\text {th }}$ century and during this process most monasteries were founded in the western parts of the new diocese in the border regions to other dioceses like Mainz. The new monasteries were erected at the western and southern borders at regular intervals. The distance between the monasteries increased from the north to the south. At the western border the distance was around 25 to 50 kilometers and at the southern border the distance increased up to 80 kilometers. The eastern parts of the diocese were completely free of monasteries. This area corresponded with the region of Slavic influence and therefore with the area of mission of the diocese of Würzburg. In addition it was not necessary to establish a border to another diocese in this region. Another factor for the geographical focus to the west, especially the north-west, was the activity of the monastery of Fulda, which founded new monasteries by itself and received monasteries founded by nobles $^{36}$. In the $10^{\text {th }}$ century no new foundation of a monastery is documented for sure. Only the monastery in Homburg is documented for the first time in the year 993, but its foundation should have taken place in the $9^{\text {th }}$ century ${ }^{37}$. Maybe the monasteries in Schweinfurt (after 980) $)^{38}$ and Stift Haug $(995-1002)^{39}$ were founded in that century.

The second period of the foundation of monasteries started in the $11^{\text {th }}$ century and reached its climax in the $13^{\text {th }}$ century. It could be expected that after the foundation of the diocese of Bamberg most of the new monasteries

35 For the first time the monastery in Mosbach is documented in a memorial book of the monastery in Reichenau in the year 826. See S. Petersen, Geistlichen Gemeinschaften, p. 159; F. Büll, Klöster Frankens, p. 30 .

36 F. Büll, Klöster Frankens, p. 10; S. Petersen, Geistlichen Gemeinschaften, p. 172.

37 S. Petersen, Geistlichen Gemeinschaften, p. 168.

38 J. Scherbaum, Die Peterstirn bei Schweinfurt, in: Vor 1000 Jahren, ed. E. Schneider, B. Schneidmüller, Schweinfurt 2004, pp. 189-207, pp. 190-192.

39 E. Bünz, Stift Haug in Würzburg. Untersuchungen zur Geschichte eines fränkischen Kollegiatstiftes im Mittelalter, Göttingen 1998, pp. 80-85. would have been founded at the border to this new diocese. But this is not the case. While it is the case that the number of monasteries in the eastern parts of the diocese increased, only the monastery in Banz (around 1070) ${ }^{40}$ was placed close to the border to Bamberg. In the $12^{\text {th }}$ century the monastery in Mönchsröden $(1149)^{41}$ and in the $13^{\text {th }}$ century in Sonnefeld $(1268)^{42}$ followed. The wave of foundations increased especially by the appearance of the new congregations of the Cistercians and the Premonstratensians in the $12^{\text {th }}$ century and with the establishment of the monastery in Ebrach, the Cistercian entered the diocese of Würzburg in the year $1127^{43}$. Until the end of the $12^{\text {th }}$ century the number of the monasteries of the Cistercians increased up to seven. The Premonstratensians settled within the diocese with their first monastery in Oberzell (1130), as well ${ }^{14}$. Also in the $12^{\text {th }}$ century the Orders of Knights appeared in the area of the diocese with the establishment of the Order of St. John in Reichardsroth (before 1192) ${ }^{45}$. The $13^{\text {th }}$ century was the climax of the second stage due to the fact that the foundation of monasteries of the Cistercians, Premonstratensians and the Orders of Knights went on. Now the Teutonic Order founded its first settlement in the diocese of Würzburg in Mergentheim $(1219)^{46}$. The mendicant orders had a huge share of the spreading of monasteries. They entered the area of the diocese shortly after their foundation. All of them started to spread in the cathedral city, except for the Hermits of St. William. They founded the first monastery in the diocese of Würzburg at

\footnotetext{
$40 \mathrm{~A}$. Wendehorst, Die Benediktinerabtei St. Petrus und St. Dionysius in Banz, München 2009, p. $320 \mathrm{f}$.

41 R. Butz, G. Melville, 850 Jahre Mönchröden, Coburg 1999, p. 37.

$42 \mathrm{~A}$. Treiber, Die Frauenklöster in Franken, in: Zisterzienser in Franken, ed. W. Brückner, J. Lenssen, Würzburg 1991, pp. 99-130.

43 S. Petersen, Geistlichen Gemeinschaften, p. 201.

44 S. Petersen, Süddeutsche Prämonstratenserstifte, pp. 9-11.

$45 \mathrm{~K}$. Borchardt, Die geistlichen Institutionen in der Reichsstadt Rothenburg ob der Tauber und dem zugehörigen Landgebiet von den Anfängen bis zur Reformation, Neustadt a. d. Aisch 1988, p. 117

46 B. Klebes, Der Deutsche Orden in der Region Mergentheim im Mittelalter. Kommende, Stadt- und Territorialherrschaft (1219/20 bis ca. 1525), Marburg 2002, p. 31.
} 
Sinnershausen (around 1292) ${ }^{47}$. Even before the ratification of the pope the Franciscans founded their monastery in Würzburg in the year $1221^{48}$. The Dominicans ${ }^{49}$ and the Ordo Sanctae Mariae Magdalenae ${ }^{50}$ followed in the year 1227. After this the female Domini- founded at all and only one of the Premonstratensians at Kreuzfeld $(1353)^{55}$. In the first period the dualism of the diocese of Würzburg and the monastery Fulda was the engine of the foundation of monasteries, now the efforts to the territorialism played this role. The noble

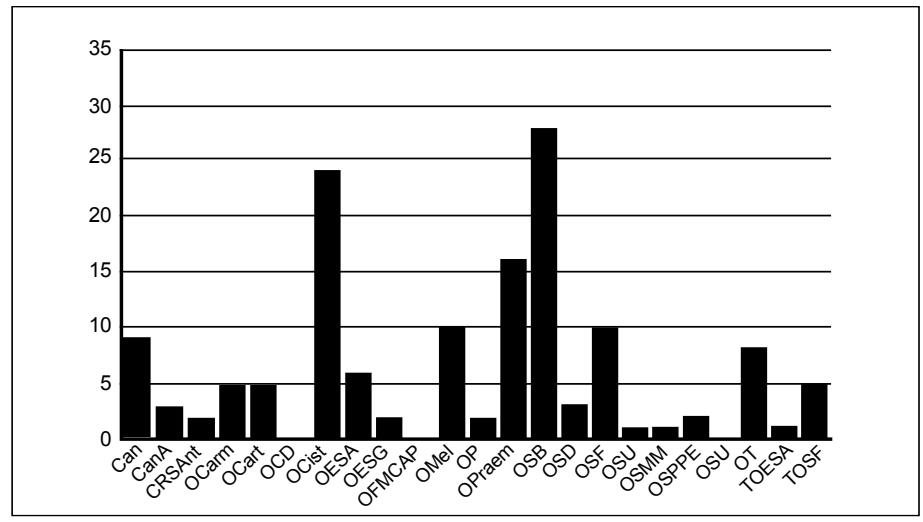

Fig. 2. Number of foundations during the second period

cans $(1244)^{51}$, the Franciscan Clarist Order $(1254)^{52}$, the Carmelite Order (before 1265) ${ }^{53}$ and the Order of Hermits of St. Augustine $(1262)^{54}$ arrived in the cathedral city. The $13^{\text {th }}$ century brought an increase of density of monasteries to the east of the diocese, and in the border regions of the dioceses of Worms and Speyer. Furthermore, there were more foundations in the northern border region to Mainz, while fewer foundations existed at the western border. During the $14^{\text {th }}$ century the variety of orders further increased with the appearance of the third order of St. Francis and St. Dominic and of the Charthusian. In contrast to this, no Cistercian monasteries were

\footnotetext{
$47 \mathrm{H}$. Matthes, Die thüringischen Klöster und ihre allgemeine Bedeutung. Ein Beitrag zur Kulturgeschichte Thüringens, Jena 1955, p. 91.

48 G. Melville, Die Welt der mittelalterlichen Klöster, München 2012, pp. 181-196; M. Sehi, Die Bettelorden in der Seelsorgegeschichte der Stadt und des Bistums Würzburg bis zum Konzil von Trient. Eine Untersuchung über die Mendikantenseelsorge unter besonderer Berücksichtigung der Verhältnisse in Würzburg, Würzburg 1981, p. 34. 49 M. Sehi, Bettelorden, p. 43.

50 I. Heeg-Engelhard, Die Frauenklöster, in: Geschichte der Stadt Würzburg, vol. 1, ed. U. Wagner, Stuttgart 2001, pp. 272-294.
}

families tried to distinguish their dominions by the foundation of monasteries. For example, in the eastern parts of the diocese the Henneberger established mainly monasteries of the Praemonstratensians. The new diversity in the way of monastic life and the territorialism of the nobles caused a monastic penetration of the whole area of the diocese of Würzburg during the second wave $e^{56}$.

Just prior to the Peasants' War the diocese of Würzburg owned a flourishing landscape of monasteries with 144 houses. In its course and by the installation of the Reformation the number decreased to only 57 in the year 1600 . But with the renovation of the deserted mon-

\footnotetext{
51 M. Sehi, Bettelorden, p. 91.

52 I. Heeg-Engelhard, Die Frauenklöster, p. 293.

53 M. Sehi, Bettelorden, p. 91.

${ }^{54}$ T. Beckmann, A. Zumkeller, Geschichte des Würzburger Augustinerklosters von der Gründung im Jahre 1262 bis zur Gegenwart, Würzburg 2001, p. 3.

55 I. Heeg-Engelhard, Oberzell und die ihm unterstellten Niederlassungen der Prämonstratenserinnen bis zur Mitte des 16. Jahrhunderts (insbesondere die Stifte Unterzell und Gerlachsheim), in: Oberzell, ed. H. Flachenecker, W. Weiß, Würzburg 2006, pp. 249-288.

56 S. Petersen, Geistlichen Gemeinschaften, p. 255.
} 


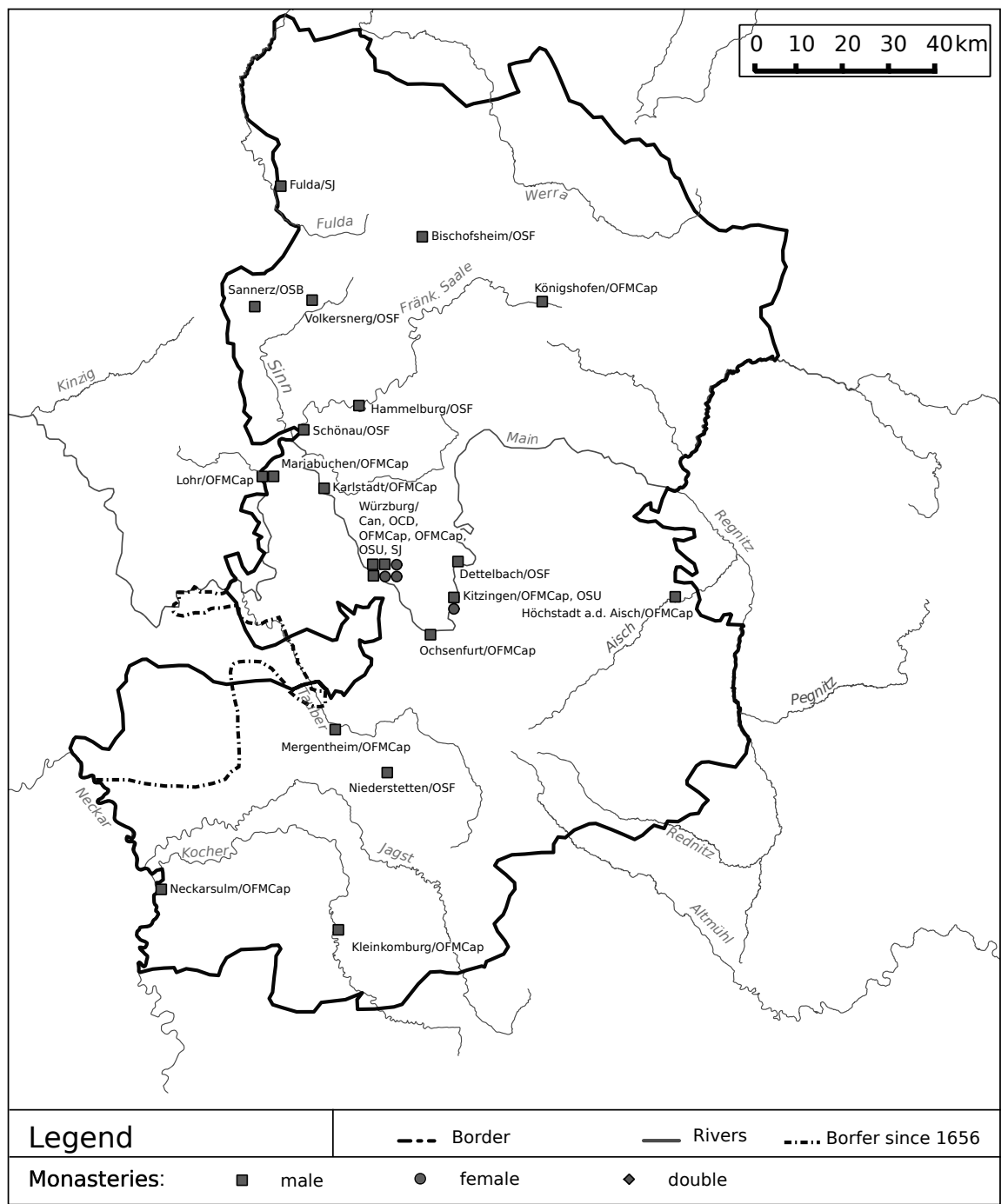

Map 4. The third period (1615-1749)

astery at Thulba by the Benedictines in $1530^{57}$ and because of the Counter-Reformation the Jesuits came to Würzburg $(1567)^{58}$ and Fulda $(1572)^{59}$. The third wave of foundations started at the end of the $16^{\text {th }}$ century. It was

57 H. Wagner, Thulba, in: Germania Benedictina, [in printing].

58 W. Zeissner, Klöster, Stifte und religiöse Gemeinschaften, in: Unterfränkische Geschichte, vol. 4,2, ed. P. Kolb, Würzburg 1999, pp. $109-160$, p. $140 \mathrm{f}$.

59 W. A. Mühl, Die Aufklärung an der Universität Fulda mit besonderer Berücksichtigung der philosophischen und juristischen Fakultät (1734-1805), Fulda 1961, p. 1. characterized by the fact that with the exception of St. Anna $\left(1690^{60}\right)$ and the monastery of the Benedictines at Sannerz $(1704)^{61}$ only monasteries of the mendicant orders were founded. The Franciscans and a new order - the Capuchins - were the most important orders of this period. Apart from St. Anna and the monasteries of the Ursulines at Kitzingen

60 N. Backmund, Kollegiat- und Kanonissenstifte, p. 141.

61 A. Wendehorst, Stadt und Kirche, in: Geschichte der Stadt Würzburg, vol. 2, ed. U. Wagner, Stuttgart 2001, pp. 308-326, p. 322 f. 
$(1660)^{62}$ and Würzburg $(1712)^{63}$ only monasteries for men were founded. This third wave could not rebuild the landscape of monasteries in the diocese of Würzburg as a whole. It ends in the middle of the $18^{\text {th }}$ century. On the eve of the secularization only 69 monasteries existed. of a monastery. Because of that it is necessary to add two more columns to show this. The columns "from" and "till" show the period for the attributes of the monastery. If one attribute changes, it will cause a new dataset for the monastery. This follows the method Naser

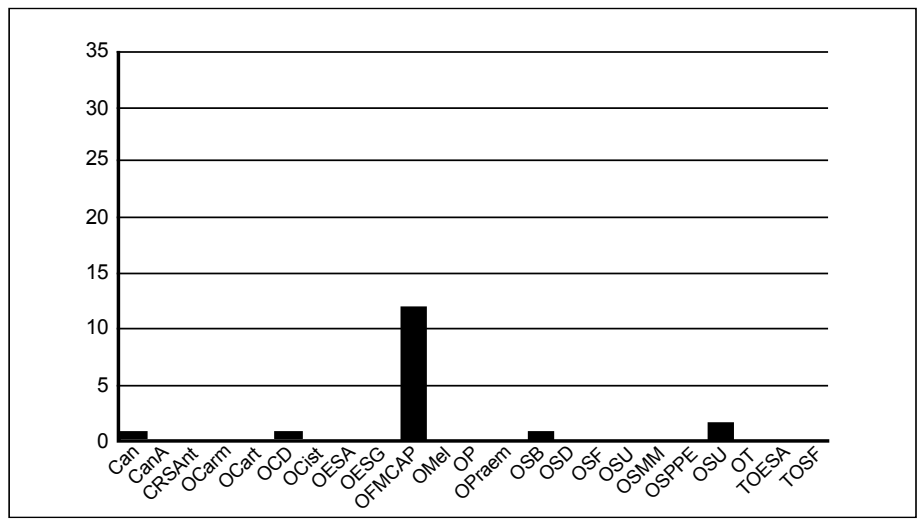

Fig. 3. Number of foundations during the third period

With the year 1802 the process of secularization started and at its end only 15 monasteries could survive. Apart from St. Anna they were all houses of the mendicant orders. At the south of the diocese no monastery survived, as well as in the east.

This short summary of the development of the monastery landscape of the diocese of Würzburg shows that this process went on in three different stages with different characteristics. Now we have to see how this development can be shown by the use of a WebGIS-application. It will show how to build a historical WebGIS-application only by using open source software and put the point of view on this technology which is useful to publish historical researches not only for historians. The first step is to store the data in a MySQL-database, which includes all attributes of the monasteries. For this example only one table is necessary. The basic columns are the ID, the place, the date of foundation, the date of closing, the sex, the order and the diocese the monastery belongs to.

But one has to realize that some of these attributes could change during the "lifetime" used in his GIS for the cities in Franconia ${ }^{64}$. The date of foundation will only be added to the first dataset of a monastery and by the same method the date of closing will only be added to the last dataset. This ensures that only one dataset of the monastery will be shown by the query for the date of foundation or closing. In the same way only one dataset per monastery will be shown by asking for all monasteries existing to a certain time. For this query the columns "from" and "till" will be used.

Even the foundation dates, not only of the early monasteries, are not certain. So the date of the first mention or the first possible date of the foundation would be added to the column "foundation". If we can only figure out the terminus post and ante quem of the foundation, it is necessary to add another column called "status" in order to show the status of this dataset. This is valid for all other attributes. We have seen that every query delivers only

\footnotetext{
62 N. Backmund, Kleinere Orden, p. 100.

63 Ibidem, p. 105.

64 M. Naser, Digitale Karten zur Geschichte der Städte in Franken, Würzburg, Baunach 2010, pp. 203-214.
} 
one dataset as a result for one monastery, but the user might be interested in the whole development of the monastery. For this case the column called "info" stores a short text with the most important information about its history. These texts have to be given in all datasets of one monastery. Now we have included all attributes which are necessary in order to describe the historical development of the monasteries. The next step is to add some columns to display them on the WebGIS. Therefore we need to add the columns for latitude and longitude to the table. It is possible to do so by using two columns or by adding one column for a WKT-string. WKT or Well-Known Text is a markup language which describes vector geometries like points in the format POINT (longitude latitude) ${ }^{65}$. For our example we will add two columns. It is possible to display the monasteries with custom icons. Therefore we need three columns. The first is called icon in order to store the path to the png-file of the icon. The next one is called iconSize, to set up a custom size for the icon. The last is called iconOffset to locate the icon in the map.
Now we are ready to build the WebGIS ${ }^{66}$. Therefore we need three files. The start. html-file creates the main page, containing the query screen and the map. For the communication with the MySQL-database the txt. $p h p$-file is needed, which queries the database and sends the results as a txt-file back to the main page. The $d b \_$info.php-file is only needed to store the connection-string, which is needed to access the database.

The structure of the start.html-file is very simple, after including the OpenLayers library, the div containing the map could be built. OpenLayers cannot deal with shape files. For that reason it is necessary to store the data in a format which OpenLayers is able to read. With QuantumGIS it is possible to export shape files to some other formats like GML and to store those files in the web folder which contains the html and $p h p$ files. In order to show the changes of the borders of the diocese described above, it is necessary to build a layer for each border and choose the one needed via a simple if-term depended on the query of the user. The layer containing the monasteries is

\begin{tabular}{|l|l|}
\hline \multicolumn{1}{|c|}{ Column } & \multicolumn{1}{c|}{ Explanation } \\
\hline ID & Primary ID for the dataset \\
\hline Place & Place of the monastery \\
\hline Foundation & $\begin{array}{l}\text { Date of the first mention or first possible date for the } \\
\text { foundation }\end{array}$ \\
\hline From & Period for the dataset \\
\hline Till & Date, or latest possible date of closing \\
\hline Closing & Sex of the members \\
\hline Sex & Congregation of the monastery \\
\hline Order & Diocese the monastery belonged to \\
\hline Diocese & Status of the dataset (safe or unsafe) \\
\hline Status & $\begin{array}{l}\text { Short text with the most important information about } \\
\text { the history of the monastery. (Given in all datasets of } \\
\text { a monastery) }\end{array}$ \\
\hline Info & Latitude \\
\hline Lat & Longitude \\
\hline Lon & Link to the png-file storing the icon \\
\hline Icon & Sets the iconsize \\
\hline Iconsize & Places the icon in the map \\
\hline Iconoffset &
\end{tabular}

65 M. Jansen, T. Adams, OpenLayers. Webentwicklung mit dynamischen Karten und Geodaten, München 2010, pp. 32-35.

66 The application is based on some examples found in books and on webpages. C.f. M. Jansen, T. Adams, OpenLayers, especially chapter
9; OpenLayers Examples, access on-line: http://www.openlayers. org/dev/examples, 10.12.2013, and OpenLayers Dynamic POI. access on-line: http://wiki.openstreetmap.org/wiki/OpenLayers Dynamic_POI, 10.12.2013. 


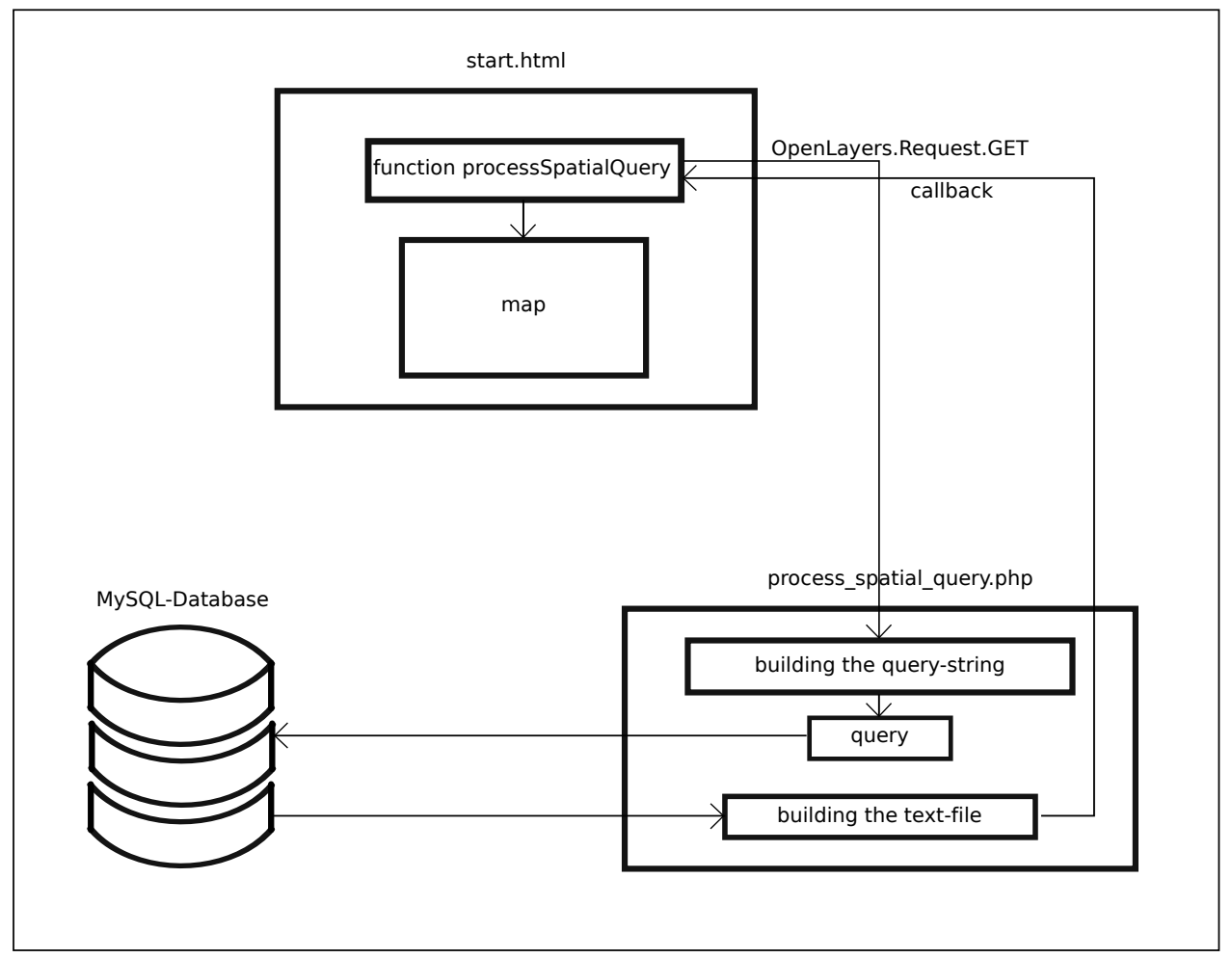

Fig. 4. Structure of the WebGIS application

a simple vector layer, but to fill it with points we need the function processSpatialQuery based on an example of Jansen and Adams ${ }^{67}$. This function sends the users input via an OpenLayers Get-Request to the txt.php-file and handles the response to create the vector features for the monastery-layer. In the original example the callback-function awaits only one WKT-string, but in our case we get a whole text-file with more than one monastery. So the code must be customized.

$/ /[\ldots]$

callback: function(req) \{

// Getting the answer of the text.php file.

var response = req.responseText $\|$ ";

// If the answer starts with the string

"ERROR", printing out the

// information. if $((/ \wedge$ mistake $/)$.test(response) $\|$ response

$===")\{$

alert(response);

\} else \{

var text $=$ new OpenLayers.For-

mat.Text();

// Builds the vector features by reading the responded text-// file var feature $=$ text.read (response); if (feature) \{

$/ / \ldots$ and adds them to the vector layer.

vectorLayer.addFeatures(feature);

\} else \{

// If the responded file doesn't

contain data in a

// readable format.

alert('Can't read the answer.'); \}

67 See M. Jansen, T. Adams, OpenLayers, pp. 250 and 254. 
The map shows only the information of the selected time, but the users might like to get more information about the monasteries. Therefore it is useful to include info windows, which shows the text given in the column "info".

As the example of the WebGIS-application of the monasteries of the diocese of Würzburg has shown, it is possible to publish historical research in the World Wide Web only by the use of open source software. It is just a minimal working example and still in progress. Therefore it should be increased. But as we have seen, it is possible to create such applications without spending money on expensive software licenses with the help of free online examples. It is possible to teach oneself and to get the skills to use it. In the future there should be a discussion about the standardization of the huge numbers of historical WebGIS applications which already exist and which will be built. We have to find a proper solution of how to show the dimension of time and the changes which take place in it by the help of such applications. One way the author tried to give

\section{Bibliography}

Backmund N., Die Chorherrenorden und ihre Stifte in Bayern, Passau 1966.

Backmund N., Die kleineren Orden in Bayern und ihre Klöster bis zur Säkularisation, Windberg 1974.

Backmund N., Die Kollegiat- und Kanonissenstifte in Bayern, Winderg 1973.

Bavaria Franciscana Antiqua, München 19551961.

Beckmann T., Zumkeller A., Geschichte des Würzburger Augustinerklosters von der Gründung im Jahre 1262 bis zur Gegenwart, Würzburg 2001.

Bendel F. J., Die Würzburger Bistumsmatrikel aus der Mitte des 15. Jahrhunderts, „Würzburger Diözesangeschichtsblätter”, 2, 1934, pp. 1-46.

Borchardt K., Die geistlichen Institutionen in der Reichsstadt Rothenburg ob der Tauber und dem zugehörigen Landgebiet von den Anfängen bis zur Reformation, Neustadt a. d. Aisch 1988.

Brückner W., Lenssen J., Zisterzienser in Franken, Würzburg 1991. follows the method of Markus Naser, but with the extension of the column "status" to show if the information given about the monastery is safe or unsafe. The GIS of the monasteries of the diocese of Würzburg will be published in 2014 on the webpage "Historisches Unterfranken", which already contains a WebGIS of the history of Franconian cities by Markus Naser using an ArcGIS-Server-application, and some databases to historical topics of the history of Franconia, supported by the chair of "Fränkische Landesgeschichte" of the University of Würzburg ${ }^{68}$. One example for a historical database on this webpage is the digital edition of the "Hohe Registratur des Lorenz Fries". The project makes the register accessible and connects the original text - given as a picture - with a regest. The regest is connected with the indices for persons, places and objects. Also the original keyword, which was used by Lorenz Fries to order the entries in an alphabetic way, will be given. This method allows the user to use the "Hohe Registratur" in a comfortable way.

Büll F., Die Klöster Frankens bis zum neunten Jahrhundert, „Studien und Mitteilungen zur Geschichte des Benediktinerordens und seiner Zweige", 104, 1993, pp. 9-40.

Bünz E., Stift Haug in Würzburg. Untersuchungen zur Geschichte eines fränkischen Kollegiatstiftes im Mittelalter, Göttingen 1998.

Burkard D., Rechtsfiktion und Rechtspraxis bei der Neuordnung der deutschen Bistumsgrenzen im 19. Jahrhundert, w: Bistümer und Bistumsgrenzen vom frühen Mittelalter bis zur Gegenwart, ed. E. Klueting, H. Klueting, H.-J. Schmidt, Rom 2006, pp. 221-246.

Burkardt J., Hünfeld, in: Die benediktinischen Mönchs- und Nonnenklöster in Hessen, ed. F. Jürgensmeier, St. Ottilien 2004, pp. 653-657.

Büttner K.-P., Die fränkischen Kartausen, in: Die Geschichte des Kartäuserordens, vol. 1, ed. J. L. Hogg, Salzburg 1991, pp. 33-57.

${ }^{68}$ See website http://www.historisches-unterfranken.uni-wuerzburg. de/ (accessed July 29, 2014). 
Büttner K.-P., Die unterfränkischen Kartausen, in: Kartäusermystik und -Mystiker, ed. J. L. Hogg, Salzburg 1981, pp. 56-82.

Butz R., Melville G., 850 Jahre Mönchröden, Coburg 1999.

Decker A., Die Karmeliten in Bayern zwischen Reformation und Säkularisation, "Zeitschrift für Bayerische Landesgeschichte”, 53 1990, pp. 3-49.

Flachenecker H., Bistum Würzburg, in: Die Bistümer des Heiligen Römischen Reiches, ed. E. Gatz, C. Brodkorb, H. Flachenecker, Freiburg im Breisgau 2003, pp. 831-870.

Gatz E., Atlas zur Kirche in Geschichte und Gegenwart, Regensburg 2009.

Heeg-Engelhard I., Die Frauenklöster, in: Geschichte der Stadt Würzburg, vol. 1, ed. U. Wagner, Stuttgart 2001, pp. 272-294.

Heeg-Engelhard I., Oberzell und die ihm unterstellten Niederlassungen der Prämonstratenserinnen bis zur Mitte des 16. Jahrhunderts (insbesondere die Stifte Unterzell und Gerlachsheim), in: Oberzell, ed. H. Flachenecker, W. Weiß, Würzburg 2006, pp. 249-288.

Hemmerle J., Die Benediktinerklöster in Bayern, Augsburg 1970.

Hochholzer E., Benediktinisches Mönchtum in Franken vom 12. bis zum 17. Jahrhundert, Münsterschwarzach 2000.

Jansen M., Adams T., OpenLayers. Webentwicklung mit dynamischen Karten und Geodaten, München 2010.

Jürgensmeier F., Die benediktinischen Mönchs-und Nonnenklöster in Hessen, St. Ottilien 2004.

Jürgensmeier F., Diözesane Grenzkorrekturen und Beilegung territorialer Differenzen zwischen Kurmainz und Würzburg 1656, in: Beiträge zu Kirche Staat und Geistesleben, ed. G. Christ, J. Schröder, R. Salzmann, Stuttgart 1994, pp. 112-130.

Klebes B., Der Deutsche Orden in der Region Mergentheim im Mittelalter. Kommende, Stadt- und Territorialherrschaft (1219/20 bis ca. 1525), Marburg 2002.

Koch R., Das Kloster St. Gumbertus und Chorherrenstift St. Gumbert zu Ansbach, in: 1250 Jahre Bistum Würzburg, ed. J. Lenssen, L. Wamser, Würzburg 1992, pp. 229-234.

Koller M., Kartäuser in Franken, Würzburg 1996.

Leinweber J., Burkardt J., Rasdorf, in: Die benediktinischen Mönchs- und Nonnenklöster in Hessen, ed. F. Jürgensmeier, St. Ottilien 2004, pp. 910-912.

Lübeck K., Fuldaer Nebenklöster in Mainfranken, „Mainfränkisches Jahrbuch für Geschichte und Kunst", 2, 1950, pp. 1-52.

Machilek F., Das Protokoll der Frankfurter Synode vom 1. November 1007 und die Errichtung des Bistums Bamberg, in: Das Bistum Bamberg um 1007, ed. J. Urban, Bamberg 2006, pp. 16-44.

Matthes H., Die thüringischen Klöster und ihre allgemeine Bedeutung. Ein Beitrag zur Kulturgeschichte Thüringens, Jena 1955.

Melville G., Die Welt der mittelalterlichen Klöster, München 2012.

Mühl W. A., Die Aufklärung an der Universität Fulda mit besonderer Berücksichtigung der philosophischen und juristischen Fakultät (1734-1805), Fulda 1961.

Naser M., Digitale Karten zur Geschichte der Städte in Franken, Würzburg, Baunach 2010.

Petersen S., Die geistlichen Gemeinschaften im mittelalterlichen Bistum Würzburg. Ein Überblick, in: Franken und Südtirol, ed. H. Flachenecker, H. Heiss, Innsbruck 2013, pp. 157-267.

Petersen S., Die süddeutschen Prämonstratenserstifte. Anfänge - regionale Vernetzung - Kurienkontakt, Würzburg 2008.

Scherbaum J., Die Peterstirn bei Schweinfurt, in: Vor 1000 Jahren, ed. E. Schneider, B. Schneidmüller, Schweinfurt 2004, pp. 189-207.

Schmid H., Kurzlebige Pauliner-Klöster in Schwaben, Franken und am Oberrhein, „Zeitschrift für Württembergische Landesgeschichte”, 45, 1986, pp. 103-116.

Sehi M., Die Bettelorden in der Seelsorgegeschichte der Stadt und des Bistums Würzburg bis zum Konzil von Trient. Eine Untersuchung über die Mendikantenseelsorge unter besonderer Berücksichtigung der Verhältnisse in Würzburg, Würzburg 1981.

Steinel L., Pfarreien-Austausch zwischen Würzburg und Mainz im Jahre 1656, „FreiburgerDiözesanarchiv", 37, 1909, pp. 224-231.

Störmer W., Entwicklungstendenzen in der ostfränkischen Klosterlandschaft der Karolingerzeit, in: Mittelalterliche Klöster und Stifte in Bayern und Franken, ed. W. Störmer, St. Ottilien 2008, pp. 159-184.

Störmer W., Zur kulturellen und politischen Bedeutung der Abtei Amorbach vom 8. bis zum 
frühen 12. Jahrhundert, in: Mittelalterliche Klöster und Stifte in Bayern und Franken, ed. W. Störmer, St. Ottilien 2008, pp. 201-226.

Treiber A., Die Frauenklöster in Franken, in: Zisterzienser in Franken, ed W. Brückner, J. Lenssen, Würzburg 1991, 99-129.

Unger L., Johannesberg, in: Die benediktinischen Mönchs- und Nonnenklöster in Hessen, ed. F. Jürgensmeier, St. Ottilien 2004, pp. 603-632.

Weiss D. J., Die Geschichte der Deutschordensballei Franken im Mittelalter, Neustadt a. d. Aisch 1991.

Wendehorst A., Benz S., Verzeichnis der Säkularkanonikerstifte der Reichskirche, "Jahrbuch für Fränkische Landesforschung", 54, 1994, pp. 1-174.

Wendehorst A., Das benediktinische Mönchtum im mittelalterlichen Franken, in: Untersuc- hungen zu Kloster und Stift, Göttingen 1980, pp. 38-60.

Wendehorst A., Das Bistum Würzburg, vol. 1, Berlin 1962.

Wendehorst A., Die Benediktinerabtei St. Petrus und St. Dionysius in Banz, München 2009.

Wendehorst A., Stadt und Kirche, w: Geschichte der Stadt Würzburg, vol. 2, ed. U. Wagner, Stuttgart 2001, pp. 308-326.

Zeissner W., Klöster, Stifte und religiöse Gemeinschaften, in: Unterfränkische Geschichte, vol. 4,2, ed. P. Kolb, Würzburg 1999, pp. 109-160.

Zumkeller A., Die Bedeutung der Augustiner für das kirchliche und religiöse Leben in Franken und Thüringenwährend des 14. Jahrhunderts, „Würzburger Diözesangeschichtsblätter", 18-19, 1956-1957, pp. 33-52.

\section{Klasztory diecezji Würzburg jako projekt WebGIS}

\section{Streszczenie}

Niniejszy artykuł podzielono na dwie części, przy czym pierwsza opisuje rozwój krajobrazu klasztornego diecezji würzburskiej od jej ustanowienia do roku 1818. Rozwój ten był podzielony na trzy różne etapy o odmiennym charakterze. $\mathrm{O}$ ile podczas pierwszego etapu założone zostały tylko klasztory benedyktyńskie i kanonickie, to drugi etap charakteryzował się ogromnym pluralizmem zakonów. W trzecim etapie, po okresie reformacji, która spowodowała za- mknięcie wielu klasztorów, zakładano, z niewielkimi wyjątkami, tylko zakony mendykanckie. Po tym krótkim opisie rozwoju klasztorów w diecezji würzburskiej, autor podaje przykład opublikowania wyników za pomocą aplikacji web-GIS odnoszącej się do bazy danych MySQL. Po opisaniu struktury bazy danych oraz niezbędnych kolumn, podano przykład połączenia OpenLayers z bazą danych.

Słowa kluczowe: krajobraz klasztorny, diecezja Würzburg, OpenLayers, MySQL

Keywords: monastery landscape, diocese of Würzburg, OpenLayers, MySQL

Michael Weisenberger (ur. Schmitt) -studiował w Würzburgu historię średniowiecza i archeologię. Obronił pracę dyplomową pt. „Zastosowanie GIS w badaniach krajobrazu klasztornego na terenie biskupstwa würzburskiego" (2013). Od tego czasu pisze pracę doktorską dotyczącą historii uniwersytetu w Würzburgu. Dodatkowo pracuje jako asystent w zakładzie Historii Regionalnej Frankonii (Fränkische Landesgeschichte) na uniwersytecie w Würzburgu, gdzie zajmuje się opracowywaniem bazy danych dotyczącej miejsc targowych we Frankonii (e-mail: michael.weisenberg@stud-mail.uni-wuerzburg.de) 